\title{
Elimination of consequences of earthquakes on the territory of the Republic of Kazakhstan
}

\author{
Yeraly Shokbarov ${ }^{\text {i) }}$ \\ i) Candidate of Engineering Sciences, Director of the Center seismic resistance of buildings and installations, 21 Solodovnikov str, \\ Almaty, KAZAKHSTAN, Kazakh Scientific-Research Institute of Construction and Architecture.
}

\begin{abstract}
In the prolog of this work the short description of the last earthquakes which have occurred in recent years in the Republic of Kazakhstan is given. Further more detailed information on earthquake consequences is stated: destruction scales, order of works at elimination of consequences of an earthquake, methods of strengthening of buildings. At the end of article it is spoken about works of KAZNIISSA done in the field of elimination of consequences of an earthquake for existing building.
\end{abstract}

Kewords: earthquake, elimination, seismodislocation, bricklaying durability.

On May 23, 2003 there was a "Lugovsky" earthquake in the southern part of the territory of the Republic of Kazakhstan, to the west of $(350 \mathrm{~km})$ Almaty, to the east of $(100 \mathrm{~km})$ Taraz, in a point with such coordinates as: $43000^{\prime}$ of NL, 72o 44' of EL.

Epicenter of an earthquake is located in the territory of station Lugovoy and doesn't coincide with the provision of the epicenter determined by tool data. Approximately the epicenter determined by tool data is located at distance equal to $7 \mathrm{~km}$ in the direction on the northwest from the center of St. Lugovoi. In an epicenter zone at inspection of a seismodislocation on a surface of soil weren't found.

According to a network of stations of Institute of seismology of the Ministry of Education and Science of the Republic of Kazakhstan the magnitude of earthquake made 5,4 with a center depth (by different estimates) from 4 to $8 \mathrm{~km}$. Tool data regarding fluctuations of soil in an zone of epicenter weren't obtained, therefore intensity of manifestation of an earthquake was estimated on the basis of descriptive part of a seismic scale of MSK-64.

Aftershocks with intensity up to 3 points in an epicenter zone repeated almost every day within the first 4 weeks. Intensity of manifestation of separate aftershock during this period of supervision reached 6 points. The earthquake of 23.05.2003 had local character and noticeable damages to buildings and constructions were observed generally within the territory of the region of T. Ryskulov of Zhambylsky area.

The earthquake caused small, moderate and heavy damages of buildings (9707 houses) in the territory not less than 1000 sq.km with an average radius not less than $20 \mathrm{~km}$. In a zone, the most affected by an earthquake, there are located seven rural districts (15 settlements) in which 42869 persons live. The main results of macro seismic inspection are given in table 1 .
Table 1. The main results of macro seismic inspection.

\begin{tabular}{|c|c|c|}
\hline № & Name of the place & $\begin{array}{c}\text { Intensity of an earthquake } \\
\text { in points }\end{array}$ \\
\hline 1 & Lugovaya station & $7-8$ \\
\hline 2 & village of Enbekshi & 7 \\
\hline 3 & village of Kyzylsharva & 7 \\
\hline 4 & village of Kulan & $6-7$ \\
\hline 5 & village of Karakystak & $6-7$ \\
\hline 6 & village of Akbulak & $6-7$ \\
\hline 7 & village of Zhalpaksaz & $6-7$ \\
\hline 8 & village Kazakh & 6 \\
\hline 9 & village of Tassholak & 6 \\
\hline 10 & Military camp & 6 \\
\hline 11 & village of Zhaksylyk & 6 \\
\hline 12 & Military airfield & $5-6$ \\
\hline 13 & village of Kokdonen & $5-6$ \\
\hline 14 & village of Kuragata & $5-6$ \\
\hline 15 & village of Karakat & $5-6$ \\
\hline 16 & village Zhanaturmys & $5-6$ \\
\hline
\end{tabular}

Note. Data on settlements in which the earthquake was shown with intensity not less than 5 points are provided in the table.

As a result of an earthquake 3 persons were lost, 26 got wounds. All dead were children of school and preschool age.

On the basis of researches the preliminary seism isolative scheme of the Lugovsky earthquake was made (see fig. 1).

Inhabited one-storied houses with walls made of adobe, as a rule, without cellar, a rectangular shape in the plan. Beams of overlappings lean, generally on longitudinal walls.

Beams of overlappings of extensions are executed, generally with leaning on walls of houses. In many cases the rubble stone in the bases is laid dry, without solution, on soil.

Some houses are constructed without the bases or of the quarry stone of the same kind laid without solution. 


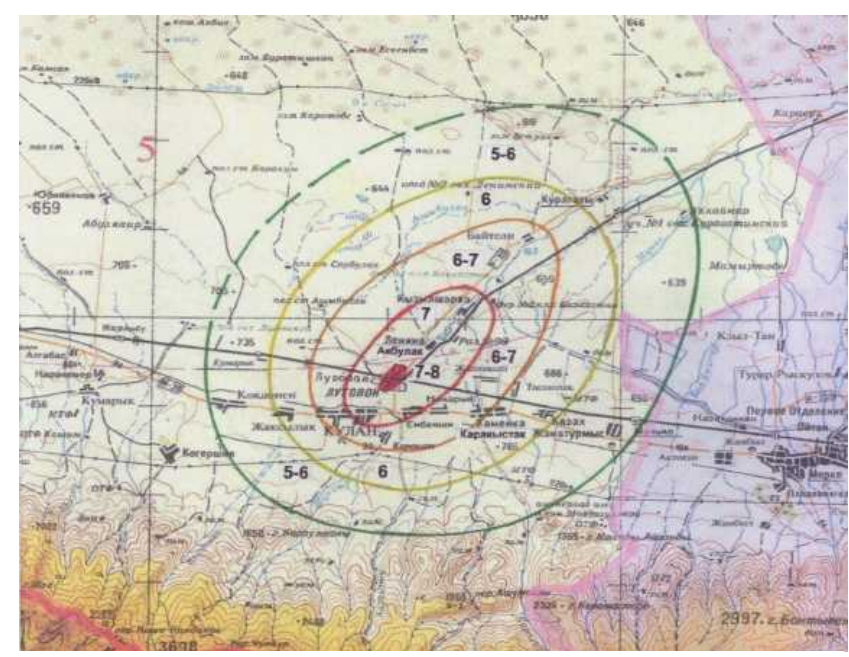

Fig.1. Isoseismics of Lugovsky earthquake.

For the houses made of adobe bricks the collapse of walls and their parts, a rupture of interfaces of walls to formation of through vertical and inclined cracks, deformations in the bearing wooden designs of coverings is characteristic.

Houses at station Lugovoy where intensity of manifestation of an earthquake on the international scale of MSK-64 made from 7 to 8 points had the greatest extent of damages. On the territory with intensity of an earthquake equal to 7 points houses sustained damage from 2 to 3 degrees. With intensity of an earthquake from 6 to 7 points houses sustained damage from 2 to 3 degrees. With intensity of an earthquake of 6 houses received, generally damages of 2 degrees. With intensity of an earthquake from 5 to 6 points houses received, generally damages from 1 to 2 degrees. At intensity of an earthquake equal to 5-6 points there were serious damages. Practically all houses with walls from adobe laying's at an earthquake not lower than 2 degrees sustained damage. About 50\% of these houses sustained damage from 2 to 3 degrees, and separate - 4 and 5 degrees (a full collapse). So serious damages of houses at intensity of an earthquake equal to 5-7 points is explained by low durability of adobe blocks used during the construction. Average durability of adobe samples on compression made 3 $\mathrm{kg} / \mathrm{cm} 2$. Damages of the houses built from an adobe bricks (see fig. 2).

Characteristic damages of buildings with the bearing brick walls are through vertical, horizontal and diagonal cracks in walls; stratifications and destruction of a laying of longitudinal walls from local damages in places of a leaning of beams of overlappings; separations of longitudinal and cross walls; shift of plates of overlappings on seams and concerning walls, disclosure of seams between plates; vertical cracks in the bases, partial and final fracture of brick pipes.

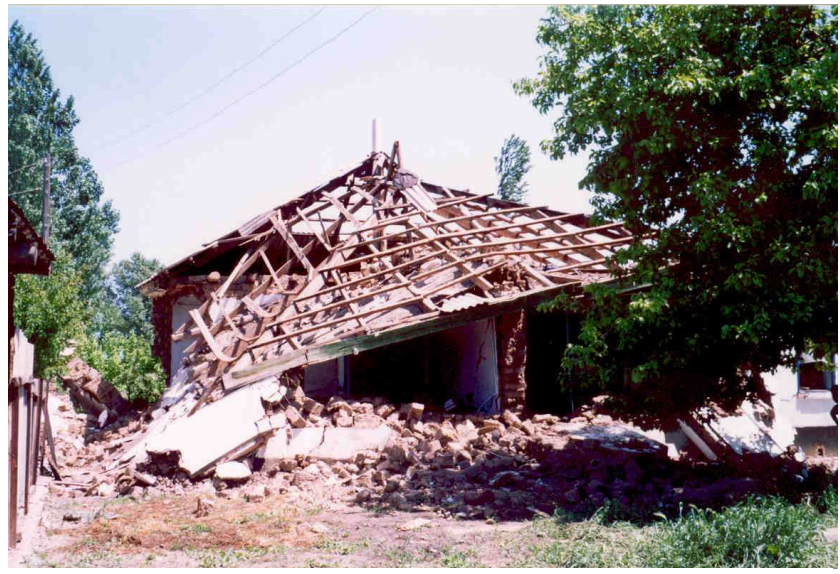

Fig.2. Destructions the adobe of houses as a result of an earthquake.

The strongest damage were sustained by low houses at station Lugovoy with maximum intensity of manifestation of an earthquake on MSK-64 scale from 7 to 8 points. Thus in buildings with wooden overlappings extent of damages was higher, than in buildings with ferroconcrete overlappings.

In houses with wooden overlappings through diagonal cracks disclosure up to $20 \mathrm{~mm}$ wide in external and internal walls are noted. Vertical cracks of a separation of face walls from longitudinal walls with shift of separate walls to $2 \mathrm{~cm}$ were observed. In places of fleecing of beams destruction of walls in the form of vertical cracks with collapses and stratification of a bricklaying took place.

Houses with wooden overlappings located in a zone with intensity of manifestation of an earthquake on MSK-64 scale from 7 to 8 points sustained damage from 2 to 3 degrees and are recommended for strengthening with transfer to complex designs. The certain houses with wooden overlappings located on water-saturated soil and the high level of ground waters higher than 3 degrees sustained damage. The lower ranks of a laying of walls of the 1st floor of these houses were in a damp state, separate bricks had layered structure, understood hands. These houses were recommended for demolition.

Large-panel houses are executed with one, two and four floors. The constructive scheme of houses is accepted with the bearing cross and longitudinal walls from ferroconcrete panels. Overlappings of one-storied and two-storied houses are executed from multihollow plates with a leaning on longitudinal (one-storied houses) and cross (two-storied houses) walls. Overlappings of four-storied houses are executed from panels with a leaning on a contour. Partitions and walls of entrance platforms are executed from a bricklaying.

As a result of an earthquake all bearing designs of buildings of this group sustained insignificant damage in the form of small cracks to seams between panels of overlappings, falls on some sites of whitewashing and plaster. In general the bearing designs of large-panel 
buildings well transferred earthquakes, and doesn't demand strengthening. On the territory of an earthquake area 15 damaged schools are located. Seven schools are executed with use of bearing brick walls. Overlappings in five of them are executed from combined ferroconcrete multihollow plates. Overlappings of two another schools are made of wooden designs. Five schools are executed with bearing brick walls of a complex design.

Three schools are executed with a ferroconcrete framework. One school is executed with the bearing wooden walls and one school is executed with bearing walls from adobe brick laying. The school buildings which underwent seismic influences of intensity of 6-8 points also sustained serious damage. From fifteen buildings of comprehensive schools:

Rub, not having aseismic actions, it was necessary to take down; instead of them by September first 3 new schools are built. Twelve, despite existence in them of some aseismic actions it was necessary to strengthen them. All these schools were put into operation by the beginning of academic year.

The main reasons for damages of school buildings were connected not so much with intensity of the seismic influences taking place, how many with poor quality of construction and the allowed derogations from design decisions. In all educational cases of schools of value of temporary resistance of a bricklaying of $\mathrm{Rp}$ changes ranging from 0,3 to 0,7 $\mathrm{kg} / \mathrm{cm} 2$ that is much lower, than established in norms (not less than 1,2 cm2).

Hospitals and policlinics - total 18, from them the 1-bearing wooden walls; 1-with bearing walls from adobe laying's; 16-s the bearing brick walls. And also big group of office buildings, social and cultural facilities, telecommunications agencies and hotels.

During the course of elimination of consequences of an earthquake to the construction organizations of the Republic of Kazakhstan 4756 houses were strengthened and repaired and 2563 new houses are built. 12 schools were strengthened. Demolished 1 regional hospital, constructed 1 new hospital, 17 hospitals were strengthened. And all administrative buildings were subject to strengthening. The economic damage caused by an earthquake exceeded $\$ 120$ million, from which $\$ 95$ million (78\%) - costs of demolition and new construction and \$27 million (22\%) - costs of strengthening of buildings and rescue and recovery operations. Elimination of consequences of an earthquake was executed by own forces of the Republic of Kazakhstan.

Demolition of such houses and construction aseismic, will lead to big material inputs. It is more expedient to strengthen houses of this design that is visible on the example of the Lugovsky earthquake.

The economic analysis shows that construction of the new house meeting the requirements of norms costs approximately $\$ 20000$, strengthening of the affected house $-\$ 5000$.

Besides, strengthening of houses considerably reduces time of introduction of housing to operation. In two weeks the institute of KAZNIISSA developed ways of strengthening of buildings. For the first time in our practice mass strengthening the adobe houses was carried out. F

or receiving complex designs it was recommended to strengthen all bearing walls of buildings by bilateral vertical slices of the high-strength reinforced plaster on cement and sand solution of brand not lower than 150 or a shotcrete concrete and not less than $40 \mathrm{~mm}$ thick on reinforcing grids from a wire with a diameter not less than $5 \mathrm{~mm}$ (see fig. 3).

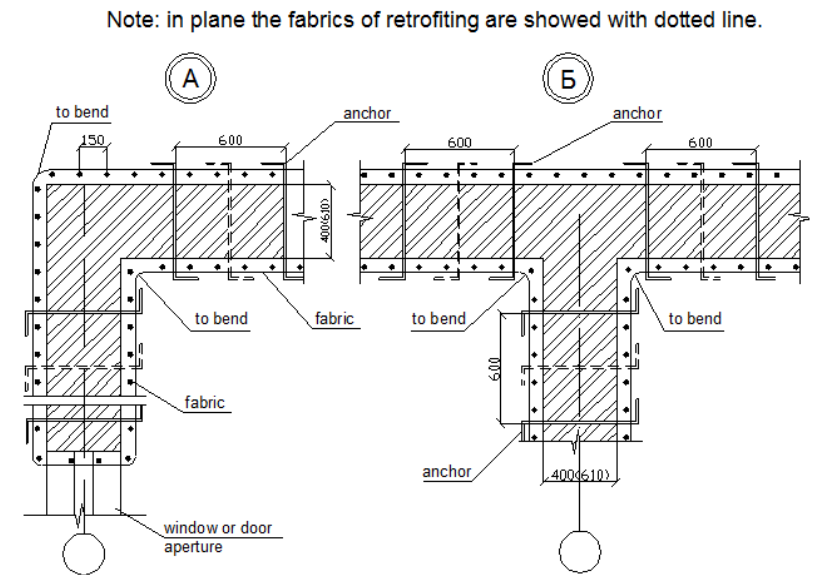

Fig.3. Strengthening the walls from adobe layings reinforcing grids in a layer of high-strength solution.

For prevention of ruptures of walls in the level of overlappings the flat reinforcing frameworks replacing aseismic belts were established on two parties of walls.

Flat frameworks were made of two longitudinal reinforcing cores of Ø12 of mm of the class A-III and cross cores of $\varnothing 6$ of $\mathrm{mm}$ of the class AI with a step of $300 \mathrm{~mm}$. For anchoring in an aseismic belt of a beam of overlappings contacted flat frameworks collars from reinforcing cores of $\varnothing 6$ of $\mathrm{mm}$ of the class AI. The bases from a rubble stone were also strengthened from two parties by reinforcing grids in a layer of fine-grained concrete of a class not less B12,5 and not less than $100 \mathrm{~mm}$ thick.

Grids were carried out from reinforcing cores of Ø8 of mm of the class A-III with sizes of cells of 200x200 $\mathrm{mm}$. At the offered way of strengthening the rigid spatial system consisting from strengthened by bilateral vertical slices of the high-strength reinforced plaster of external and internal walls was received.

For the purpose of an assessment of efficiency of the offered way of strengthening tool researches of dynamic characteristics (the periods and forms of own fluctuations, logarithmic decrements) of houses with walls from adobe, from a bricklaying before 
strengthening and the actual durability of cement and sand plaster of strengthening were conducted.

Dynamic tests showed that the periods of own fluctuations of adobe houses with damages of 3 degrees before strengthening were equal, about $0,16 \mathrm{sec}$. The periods of own fluctuations of adobe houses after strengthening were equal, $0,04 \mathrm{sec}$. Rigidity of the adobe houses after strengthening increased on average by 16 times in comparison with rigidity of not strengthened houses. Durability of cement and sand solution of strengthening was defined on 16-20 days after completion of plaster works and averaged $160 \mathrm{~kg} / \mathrm{cm} 2$. When using sand with additions of clay, use of bar khan sand durability of cement and sand solution was equal only $30-40 \mathrm{~kg} / \mathrm{cm} 2$.

In two weeks after an earthquake the institute of KAZNIISSA conducted detailed examination and there was developed project documentation on strengthening of 15 buildings of schools. Inspection showed that buildings with the bearing brick walls at an earthquake intensity of 7 points sustained strong damage (fig. 4).

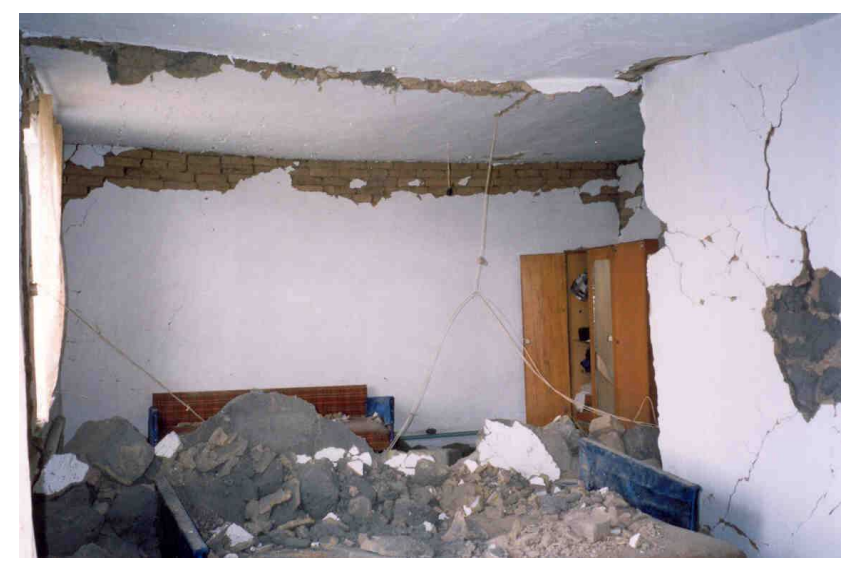

Fig.4. Damages of schools with bearing brick walls.

The buildings which sustained damage from 3 to 4 degrees are recommended for demolition. The buildings which sustained damage from 2 to 3 degrees are recommended for strengthening.

For ensuring seismic safety of buildings of schools it is recommended the following actions for strengthening:

- to transfer bearing walls from not reinforced bricklaying to category of complex designs. For this purpose it is necessary to carry out bilateral strengthening of all walls reinforcing grids in a layer of high-strength plaster from it is cement - sandy solution.

- for reduction of distances between cross walls in compartments of the building it is necessary to enter into the existing constructive scheme additional (the replacing cross walls) the steel frames of strengthening connected with overlappings and wall designs.

To strengthen brick walls and partitions of all buildings of schools reinforcing grids, established with internal and to outer sides of a wall in a layer of a gunite plaster or on high-strength cement and sand solution of brand 150 .

Thickness of a plaster coat, section and the sizes of cells of a reinforcing grid to establish on the basis of calculation of walls on horizontal seismic loadings taking into account the actual durability of a laying and a damage rate.

For the purpose of efficiency of the offered way of strengthening tool researches of dynamic characteristics (the periods and forms of own fluctuations, logarithmic decrements) buildings of schools before strengthening were conducted.

The periods of own fluctuations of buildings with brick walls before strengthening were equal, about 0,45 sec., after strengthening decreased, to $0,24 \mathrm{sec}$.

Respectively rigidity of buildings after strengthening increased 3 times. The school building in the village of Zhaksylyk with monolithic ferroconcrete frameworks with external brick walls. Designs of a monolithic ferroconcrete framework sustained strong damage at intensity an earthquake of 6 points because of the extremely poor quality of construction.

Serious damage were sustained by brick walls and partitions, getting the main part of seismic loading that rescued the building from a collapse. Buildings are recommended to strengthening: a) to strengthen columns of cross frames of a framework holders from steel corners; b) to strengthen crossbars of frames, having increased the squeezed crossbar zones, with the device in the top zone of additional reinforcing cores and grids.

Dynamic tests showed, the periods of own fluctuations of frame buildings before strengthening made, about 0,34 sec., and after strengthening about 0,2 sec. Rigidity of the building after strengthening increased on average by 3 times in comparison with rigidity to strengthening.

All schools were graduated by September first.

The general management of research and project works was carried out by head research institute of the Republic of Kazakhstan in the field of aseismic construction of KAZNIISSA. During the course of construction of KAZNIISSA by institute in again built houses and in again constructed 3 schools with bearing walls from a bricklaying durability of coupling of the laying on a separation on not tied up seams according to State standard 24992-81 sustained not less than 7 days was checked. Tests showed the following results of $0,1 \mathrm{~kg} / \mathrm{cm} 2$ to $0,4 \mathrm{~kg} / \mathrm{cm} 2$.

Low durability of coupling of a laying is explained by violation of the production technology of works. The brick kept within without soaking in water, wasn't cleared of dust. After carrying out tests of a laying for a separation quality of construction improved to the best. Durability of coupling of a laying on a separation was made by $1,2 \mathrm{~kg} / \mathrm{cm} 2$ to $2,4 \mathrm{~kg} / \mathrm{cm} 2$. Construction of new houses and strengthening of the existing houses 
was complete by the end of 2003 .

On December 1, 2003 there was an earthquake in the village of Sumbe of the Rayymbek region of Almaty region $(350 \mathrm{~km}$. to the east of Almaty) from epicenter an earthquake about $50 \mathrm{~km}$, in a point with coordinates: $42{ }^{\circ} 88^{\prime} \mathrm{NL}, 80^{\circ}{ }^{\circ} 4^{\prime}$. Intensity of manifestation of an earthquake in the territory of the village of Sumbe approximately made no more than 6 points (the assessment is executed by macro seismic part of a scale of MSK-64).

The considered objects included private houses raw - adobe laying's, executed without special aseismic events. From 576 private houses to the village of Sumbe of 506 houses are adobe, 52 houses - wooden and 18 - brick are. In total it was surveyed the buildings which are most damaged 67 adobe. Seismic influence in buildings was resulted by education and disclosure of inclined planes and vertical cracks in walls, plan metric cracks of a separation of walls and partitions, overlappings from walls etc. The received injuries of the bearing designs of walls were classified as small and moderate damages (the first and second degree). Damages of 1 degree are noted in the majority of houses, 2 degrees - in many buildings, certain houses sustained heavy damage with elements of partial destruction from 3 to 4 degrees (see fig. 5).

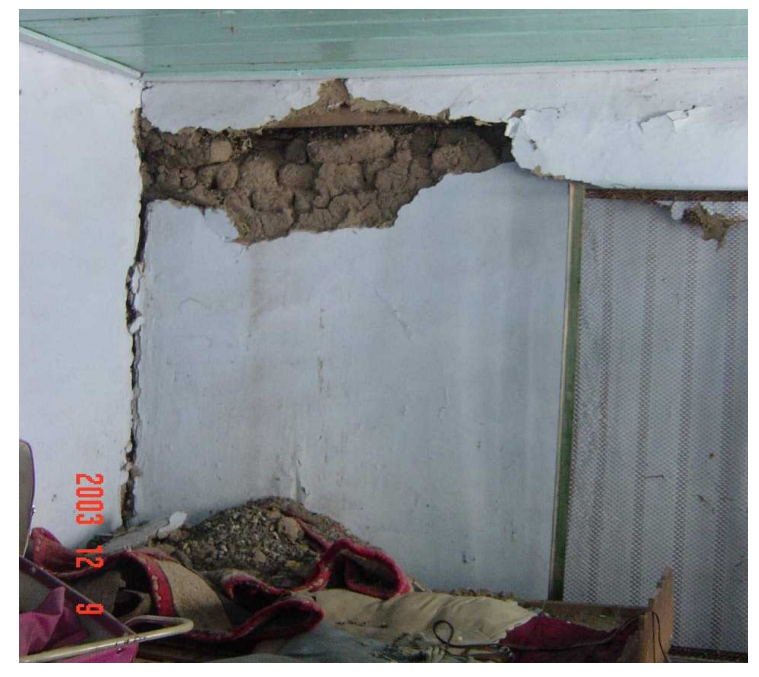

Fig.5. Destructions of adobe houses.

Thus it should be noted, poor quality of adobe laying of bearing walls practically of all objects owing to decay and the moderate and heavy damages to the bases, walls and overlappings which arose till the earthquake.

On June 13, 2009 there was an earthquake in the city of Tekeli of 6133 hectares or 0,1 thousand sq.km., is in $40 \mathrm{~km}$ on the southeast from Taldykorgan and in $285 \mathrm{~km}$ to the east from Almaty. Intensity of manifestation of an earthquake on June "13", 2009 in Tekeli made 6 points on a scale of MSK-64K. On separate sites, depending on soil conditions, on June
"13", 2009 in Tekeli made intensity of manifestation of an earthquake from 6 to 7 points.

The earthquake caused considerable and moderate damages one and two-storied houses constructed in the fifties and also the considerable damage was caused to municipal buildings. As a result of an earthquake the victims aren't present.

In a zone of the victim from an earthquake, Mr. Tekeli lives about 27 thousand people.

The economic damage caused by an earthquake made - 400 million tenge (2,7 million dollars). Elimination of consequences of an earthquake was executed by own forces. The decision to find means from the regional budget, that is, to do without support of the state was made.

Tool data on fluctuations of soil in an epicenter zone weren't obtained therefore intensity of manifestation of an earthquake was estimated on the basis of descriptive part of a seismic scale of MSK-64.

For restoration of the damaged buildings after an earthquake, the special commissions from leading experts of the Republic were organized. For decision-making expeditious examination of building of affected areas was conducted previously.

The general management of research and project works was carried out by head research institute of the Republic of Kazakhstan in the field of aseismic construction - "KAZNIISSA".

On each of the surveyed buildings the corresponding card (conclusion) in which a specification on constructive solutions of the building, data on the being available damages and the recommendation about restoration or demolition was given was formed.

In addition to cards statements of inspection of buildings were drawn up. In these acts, except the description of constructive decisions and damages, the conclusion about need of demolition, restoration with strengthening of designs or capital repairs of buildings located.

The list of especially important objects which are subject to prime restoration and strengthening, as a rule, joined school.

Inspection of building showed that, despite existence of the relevant standard and instructive documents, the vast majority of the residential buildings which appeared in a zone of an earthquake was built without any aseismic actions.

The majority of the buildings built 20-30 years ago had some aseismic actions.

However, construction was carried out with very poor quality and big derogations from projects. As a result of an earthquake practically all individual residential buildings with walls from adobe, slag stones and a brick sustained damage of 2 and 3 degrees, and some (adobe and brick) -4 degrees (fig. 6). 


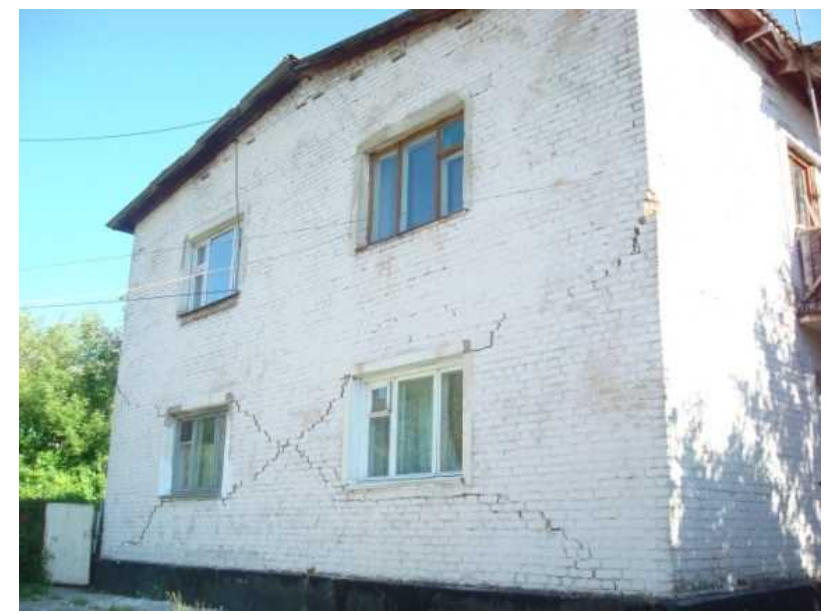

Fig.6. The inhabited two-storied houses which sustained damage in Tekeli.

The earthquake of 13.06 .09 was more shown in the territory of Tekeli 27 thousand people stay.

Practically all houses with walls from adobe laying's at an earthquake not lower than 2 degrees sustained damage.

About $50 \%$ of these houses sustained damage from 2 to 3 degrees. For the adobe houses the collapse of walls and their parts, a rupture of interfaces of walls to formation of through vertical and inclined cracks, deformations in the bearing wooden designs of coverings is characteristic.

To a lesser extent one-storied houses with the bearing brick walls were damaged, but also in this group of houses damages to the basic of 2 and 3 degrees ( $75 \%$ of their general quantity) prevail. In these houses cracks in seams between ferroconcrete plates of coverings, vertical and inclined through cracks in the bearing brick walls are observed (fig. 13).

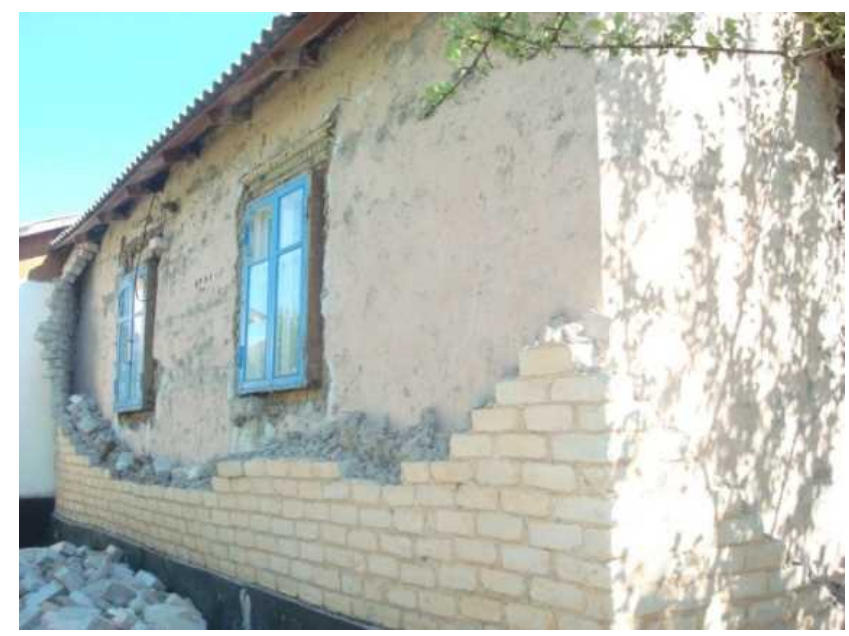

Fig. 7. The inhabited one-storied houses which sustained damage in Tekeli.

Detailed inspection is executed and recommendations about strengthening of the building of School No. 1 are developed. In two weeks the KAZNIISSA institute developed ways of strengthening of buildings. Strengthening of houses was carried out by bilateral vertical layers of the high-strength reinforced plaster on cement and sand solution of brand not lower than 150 or a shotcrete concrete and not less than $40 \mathrm{~mm}$ thick. Also the bases from a rubble laying amplified.

Construction and strengthening of houses was conducted under control of KAZNIISSA institute, together with local authorities. All recovery work is complete in full in only 2,5 months. Sub-row and subcontract organizations executed in time, having finished all necessary actions till September 1. All social and cultural facilities worked as before, before cold weather approach people received housing, and in the private sector strengthening of 22 houses is made. Due to the state help in a type of building materials 740 houses were repaired.

\section{CONCLUSIONS}

The analysis of consequences of strong earthquakes and the review of normative documents on application of adobe constructions shows that the behavior of adobe constructions at various seismic influences is a little studied, their construction is conducted without construction normative documents, without development of the project.

In this regard were developed and published by KAZNIISSA institute "Recommendations about design, construction and strengthening of houses from local construction materials (adobe, slag block) in seismic countries of Kazakhstan" and it is put into operation 2008.

\section{REFERENCES}

1. «Шкала оценки интенсивности землетрясений MSK-64 (К). -Алматы, 2004.

2. Уроки Луговского землетрясения 23 мая 2003 года в Казахстане. Программа Развития ООН в Казахстане, Алматы 2004.

3. Ashimbaev M., Tuleev T., Aldakhov S., Taubaev A., Shokbarov E. "Recommendations about design, construction and strengthening of houses from local construction materials (adobe, slag block) in seismic countries of Kazakhstan" Almaty, 2008. 